\title{
Academic Librarianship: Professional Strivings and Political Realities
}

Faculty status for academic librarians often has been discussed in the literature of librarianship, but little attention has been given to its relationship to three associated topics that bear heavily on academic librarianship: professionalization as an aspect of the sociology of librarianship; the power relationships within the institutions of higher education where academic librarians work; and the phenomenon of academic collective bargaining. This paper discusses briefly these topics as they relate to faculty status for academic librarians.

$\mathbf{F}$ OR MORE THAN a quarter of a century academic librarians in the United States have been writing and talking about, and striving for, a larger recognition of their contribution to the work of the colleges and universities they serve. In substance, these efforts have been chiefly directed toward some form of recognition within the academy, usually the granting of faculty status to librarians.

A great variety of opinions on these matters has been expressed, ${ }^{1}$ historical accounts of the status of academic librarians have been published, ${ }^{2}$ and a few surveys of opinion and of fact have been undertaken. ${ }^{3}$ In addition to these expressions of interest on the part of librarians, there have been occasional contributions by sociologists interested in the sociology of occupations and the phenomenon of professionalization. ${ }^{4}$ From this abundant literature there can be discerned certain trends in the occupation of librarianship, its advances toward professionalization, and its role in the life of the academy and in the larger matrix of American society.

David G. E. Sparks, formerly director of libraries at the University of Notre Dame, is curator of the Medieval Institute Library at that institution and a doctoral student at the Graduate Library School, Indiana University, Bloomington.
There has not been as yet any notably effective synthesis, however, of the many ideas of librarianship expressed in this literature. Most of the writers have been preoccupied with particular aspects of academic librarianship. The search for faculty rank, the definition of librarians as educators, a concern for collegial forms of governance are some of these aspects. These writers are joined by others who approach academic librarianship with borrowed concepts from the world of business and speak of participative management or collective bargaining. All these facets of the world of academic librarians are interesting and almost all of the writers have made valuable contributions t $\rho$ our understanding of the field. Nevertheless, there is a need, at present, to draw together the results of these efforts into a larger view. It is such a synthesis that is attempted in this paper.

Underneath the wide range of rhetoric in the literature of academic librarianship there are some pervasive realities. Society's equivocal acceptance of librarianship as a profession is one. The projection of that estimate of our calling in the academy is another. A greater and more encompassing reality is the growth and change of the academy itself and the tensions thus produced in the domain of our professional experience. It would seem that any discussion 
of academic librarianship and especially of faculty status for librarians should begin with these realities.

\section{Professionalism}

The study of the growth of professionalism in American society has interested sociologists for some time. There are numerous published discussions of the qualities that define an occupation as a "profession," usually accompanied by lists of criteria. Greenwood has summarized these in his article "Attributes of a Profession,"5 which was reprinted in Volmer's more comprehensive symposium on professionalization. ${ }^{6}$

Both Etzione and Goode have given attention to the movement of librarianship toward professional status. ${ }^{7,8}$ In their view of the process of professionalization they see it as a movement along a continuum, with the four full-fledged professions (medicine, law, clergy, and university teaching) at the completion end. Goode would place librarianship in the middle of this continuum, but predicts that it will not attain its goal of full professionalization.

The principal attributes of a profession have been identified by Goode as: (1) a systematic body of knowledge, and (2) a commitment to service. The authority of the professional worker, recognized by the clientele of the professional group, is derived from the body of professional knowledge. The professional group's commitment to service is usually expressed in a code of ethics (e.g., the Hippocratic oath) that places the good of the client above the personal interest of the practitioner. In the light of such express commitment and of the urgent need for the expert services, sanction and approval of professional authority is granted by the broader community.

In the literature of the sociology of occupations these attributes of professionalism have been extensively discussed, especially the aspects of the client-practitioner relationship. The degree to which librarianship possesses these attributes has also been reviewed on a number of occasions. Goode $^{9}$ suggests that librarianship is deficient in the knowledge base, which lacks a coherent, systematic body of theory, and in the client-librarian relationship, where the service posture of the librarian is one of compliance, not prescription. Hanks and Schmidt $^{10}$ express somewhat the same criticism, while proposing that a different model than that of the learned professions be made the objective for librarians. Bundy and Wasserman ${ }^{11}$ also question librarians' fulfillment of the professional ideal in the client-librarian relationship, noting the librarian's tendency as a result to become "medium-oriented" rather than clientoriented. They mention further the failure of librarians, in the employment situation, to give first loyalty to the profession rather than to the bureaucratic structure as indicating a less-than-professional posture.

The strivings of librarianship to attain stature as a profession should be seen in the context of a long history of professionalization in American culture. With the advance of technology and the increasing level of education in the work force in the United States there has been an increasing tendency for occupations to adopt professional stature as their goal. The earliest example of this tendency is civil engineering, which put forward its claim in the charter of the Institution of Surveyors in 1868. Caplow ${ }^{12}$ has written of the elements of this process, and Goode ${ }^{13}$ has traced the process for librarianship. The establishment of a professional organization, the assertion of a technological monopoly (grounded in the professional knowledge base), the promulgation of a code of ethics, and prolonged political agitation for the support of public authority in maintenance of the occupational barriers between practitioners and laypeople-these four aspects of professionalization have their expressions in the history of American librarianship. How well American librarianship has accomplished these tasks of professionalization is a subject of considerable controversy. Librarianship's generic relationship to the world of learning greatly strengthens its claims as a learned profession, although the continued weakness of the knowledge base (a lack of systematic theory) weakens it.

In the larger universe of American occupations, there are several others, such as social work, accounting, nursing, and engineering, that have achieved considerable progress toward recognition as a profession. 
The great growth of an educated labor force in the United States and the shift to whitecollar, service occupations has brought about a strong steady growth of occupations that make this claim. The tendency of a technological society to fractionalize into specialities has also contributed to that growth.

\section{EMPLOYMENT OF Professionals}

Concurrent with the drive to professionalize certain occupations, there has been a growing tendency for professionals to abandon the self-employed situation of the practitioner and to become employees in an organization. The ancient ideal of the independent practitioner whose emoluments come from the unique client-professional relationship seems to be becoming outmoded in modern American society except in certain contexts (law, medicine, and engineering) where social or economic demand for expertise makes private practice attractive. More often than not, today's professional is found within a clinic, a research institute, or even a commercial organization. Of course, not all professions actually ever achieved the archetypical ideal of the independent, practicing physician or lawyer; social workers and accountants have usually worked in an organizational setting. The growth toward such an employment situation as the norm, however, is certain. Goldenberg has commented on this process in Canadian society, with special attention to the situation of professional engineers. ${ }^{14} \mathrm{En}$ gineering is, in fact, a profession that, at an early date, saw most of its professionals in employee situations. One can hardly conceive of an aeronautical engineer in private practice, although there are still a great many civil engineers in business for themselves.

Employed professionals represent, in a certain sense, a contradiction in terms. Within an organization (a business firm, a hospital, a university, or a government agency) the professional has divided loyalties. A physician's first responsibility is to the client and to the profession, not to the hospital administrator. The same is true of the engineer who affirms with his or her professional reputation the accuracy and safety of a design, or withholds that affirma- tion despite an employer's protests (or threats). The dividing line between loyalties becomes very hazy, however, in many situations where professionals are employed: witness the legal profession's anguish over Watergate. In the last analysis, there must always be a certain tension within an organization that employs professionals, a tension between the goals and the ethical demands of the practitioner and his profession on the one hand and the goals and objectives of the organization on the other.

\section{UNIVERSITIES as ORGanizations}

Universities are organizations where this internal tension is found to an extreme degree. University teaching was mentioned above in passing as one of the full-fledged, "ancient" professions. In his special field, the university professor possesses the authority of expert knowledge and only the professor or other colleagues in that field have the power to certify a student's mastery of it. Taken together, the whole faculty of the university, each in his or her own discipline, constitute the body of professional expertise and the source of certifying authority. The university administration is powerless in this matter; it is the faculty's authority that prevails.

Yet the university administration does have power. It has the power of legal charter and economic power in the control of the organization's resources which that legal authority implies. Unlike other economic organizations, however, the university administration's power does not extend to the body of workers who create the service that is the university's product: education. In reality, for all its economic power, the university administration is the ancilla of the faculty in the central function of the organization: teaching. The tension created by the two centers of authority in a university, the professional authority of the faculty and the hierarchical or bureaucratic authority of the administration, is responsible for much of the friction that we witness in modern American universities.

While this situation of the two authorities has always existed in universities, it has been exacerbated in our times. Before World War II, American universities de- 
voted only modest resources to administration. The extended, highly articulated central bureaucracies that can be observed in present-day universities are the product of the postwar boom in higher education, the G.I. Bill, sudden population growth, and the generous participation of the federal government in hundreds of educational and research programs. This sudden growth of higher education in the postwar period and the fiscal responsibility attendant on federal largesse have encouraged the development of bureaucratic management within American universities, organizational structures that have borrowed more from the administrative techniques of business than the electronic computer.

Academic libraries have been part of the postwar growth pattern in American universities and colleges. The influx of federal monies to the campus has manifested itself in a sometimes spectacular growth of the university's library. With that growth has come an increase in and ramification of the administrative structures of the library. Traditionally those structures have been hierarchical, and their elaboration in the bureaucratic model has found an empathetic echo in the university administration's own growth. Academic librarians have, indeed, often identified with the university administration in the functional aspects of their situation. Smith has remarked on this identification and has suggested some unhappy consequences. ${ }^{15}$ For if the trend in the academy in postwar America has been toward a progressive polarization of the university between faculty and institutional authority, between faculty and institutional goals, then the developing interest of academic librarians in faculty status is at odds with their previous (continuing?) identification with the administrative hierarchy. It is to that professional dilemma that academic librarians need to turn their attention.

\section{FACULTy STATUS}

In September 1972, the Association of College and Research Libraries together with the American Association of University Professors and the Association of American Colleges published a joint statement recommending faculty status for college and uni- versity librarians. ${ }^{16}$ The action was the culmination of a long effort of the Committee on Academic Status of the University Libraries Section of ACRL and had been preceded by extensive discussion in the literature.

The topic became one of active professional concern in the period after the Second World War (coinciding with the rapid growth of higher education in that period), although it had been discussed even as early as the first decade of this century. ${ }^{17}$ There was a first concern for the acceptance of university librarians by the teaching faculty as colleagues in the educational enterprise. Lundy stated:

The general principle underlying faculty-library cooperation is the simple one that the library can function effectively only as an integral part of the whole instructional organization. ${ }^{18}$

Others expressed the same conviction. ${ }^{19,20}$ Faculty status was seen as a means "of enabling .... librarians to play a more effective role in the academic community, for they can then communicate and collaborate with the teaching faculty as peers." 21 The most faithful exponent of this view was Downs, who explored the history of university librarians' place in the academic community $^{22}$ and surveyed the profession to establish the facts of librarians' situations in the academic workplace ${ }^{23,24} \mathrm{His}$ more direct contribution to the work of the ACRL Committee on Academic Status was largely responsible for the development of the joint statement.

One justification often put forward for the claim of faculty status for librarians is an interpretation of the librarian's work as educative. The ideal of librarian-as-teacher has been pursued in its more naive guise in the form of criteria for appointment and promotions of library faculty that insist on "success in teaching" as a measure of professional growth. ${ }^{25}$ Beyond the obvious tasks of library instruction, a certain amount of strained ingenuity is evidenced in interpreting the activities of librarians as teaching to fulfill this ideal. The Model Statement of the ACRL retains this expression of the ideal. ${ }^{26}$

A far more subtle analysis of the librarian's teaching role in higher education has been developed in a reorganization study 
conducted by Swarthmore College that evolved a concept of the "teaching library," with direct responsibility for the bibliographical literacy of all graduates. ${ }^{27}$ Williamson has written of Swarthmore's teachinglibrary initiatives and made important observations about the relations between teachers and librarians in the college context. ${ }^{28}$ An application of the concept of the teaching library is in the process of realization at Sangamon State College in Springfield, Illinois. A report of these efforts at Sangamon to restructure the work of librarianship as a true teaching profession has been published by Dillon. ${ }^{29}$ Others who have written of the educative role of librarians include DePriest, ${ }^{30}$ Knapp, ${ }^{31}$ and Moriarty. ${ }^{32}$

If acceptability to the faculty is a goal of faculty status for academic librarians, then the faculty's understanding of librarians' teaching role is essential, and mere interpretive restatement of traditional library activities will probably not provide that understanding. There must be (among other things) a real change in the academic librarian's commitment to scholarship and to the life of the mind. Reichmann, for example, deplores the librarian's loss of contact with books. ${ }^{33}$ Knapp repeats the injunction that librarians must be, in addition to teachers and administrators, bookmen, working closely with scholars in their research function. ${ }^{34}$ At the end of his historical review of librarianship, Winger notes the importance to the librarian of an awareness of the intellectual problems of the times as necessary to the performance of bibliothecal functions. ${ }^{35}$

That academic librarians often fail to impress their teaching colleagues by their scholarly ability has been attributed to the failures of library education. Thompson has stated:

Perhaps the most serious indictment of the schools has been the charge that the vocational content of ... [the] curricula overshadowed the intellectual. . . . ${ }^{36}$

Others have frequently repeated the charge. Volkersz asserts that the miseducation of librarians and the technocratic rather than humanistic attitude fostered in the traditional working relationships has made it impossible for librarians to adopt collegiality. ${ }^{37}$ Smith also notes:

By concentrating their efforts on the more routine aspects of library operation, by emphasizing institutional goals and adopting bureaucratic organizational patterns, college and university librarians have effectively aligned themselves with the non-academic segments of their communities. ${ }^{38}$

He goes on to recommend a broadening and deepening of the educational base of the profession so that librarians can "assume important functions within the academic community-functions the importance of which will be recognized." 39

The ideal of the librarian-as-scholar is one that is, indeed, an important component of the struggle for status for academic librarians, but it is also one about which there are still grave doubts. ${ }^{40}$ The responsibility of the library schools in this matter (that is, the strengthening of the program of professional education for librarianship) is widely recognized. There seems to be some real uncertainty, however, whether this should be done in the direction of "information science" or by extension of the humanistic base of library school programs. In the long run, the needed improvements may require both.

\section{ACCEPTANCE OF \\ FACULTY STATUS FOR LibRaRIANS}

The actual situation of university librarians with respect to faculty status has been surveyed by Hintz, ${ }^{41}$ who distinguishes four types of academic recognition reported by his respondents:

1. Faculty rank and title (assistant professor, etc.)

2. Equivalent rank (assistant librarian, etc.)

3. Assimilated rank (librarian with the rank of assistant professor)

4. Miscellaneous other status situations In the fourth category (twenty-four respondents) are included such devices of academic recognition as "special professional faculty," etc. One can conclude from such a survey that there is much variation in actual practice in American colleges and universities, or at least a certain failure of consensus both on the part of university administrators and of librarians. In part, this uncertainty 
about the role of the librarian in American academic institutions may be attributed to the wide variation of views about librarians in the accreditation standards of regional and professional associations. Veit ${ }^{42}$ has studied the record of such standards as reported in ACRL Monograph 20 and distinguishes six categories of academic recognition for librarians, ranging from standards that require full faculty status for librarians to those that make no comment on the subject at all. It is interesting to note, here, that the Southern Association of Colleges and Secondary Schools insists on full faculty status for librarians, perhaps expressing a regional appreciation of the importance of the profession.

This uncertainty about the role of librarians in the academy has been documented by Downs, ${ }^{43}$ who identified three attitudes among librarians themselves toward faculty ștatus:

Those who advocate faculty rank for all members of the profession who work in colleges and universities, because any other method abandons the values and possibilities inherent in the collegial relationship with faculty.

Those who advocate faculty status for librarians who work in colleges and universities, but only for those who merit it by their professional maturity, scholarship, etc.

Those who would accept faculty status, but only under the conditions where librarians and librarianship are accepted on their own merits, in a "separate but equal" relationship to the faculty, judged by their own norms and recognized for their unique contribution.

In reality, both the first and second attitude spring from a desire to identify with the teaching faculty on terms of comparable or analogous contribution to the educational process. The second is perhaps the more realistic, given the present level of academic preparation of the existing corps of practitioners in the library profession and the difficulty the professoriate have in recognizing the contribution of librarians as anything more than auxiliary service. That there is, or may be, substance to the claim of librarians as educators and scholars is a question that hangs undecided in the circumambience of the American academy. The teaching-library proposals of Swarthmore College would push the decision in the direction of a carefully defined and coordinated educational role for the library, a role many of the professoriate (and the librarians!) may not yet be ready to accept.

The "separate but equal" posture toward faculty status has the laudable purpose of affirming the goals and objectives of librarianship as an independent profession. Such affirmation stands in contrast to the other two, which would make the goals and objectives of the teaching profession the librarian's. The difficulty, of course, is that the goals and objectives of the library profession are so little understood or are proposed with so little consensus in the library community that it is difficult to defend to the teaching faculty an educative role for librarians (separate but equal) that merits the status of "professional." Librarians are thrown back again on the question of their own identity as a learned profession and society's (and the professoriate's) acceptance of that identity.

These are formidable questions that confront the academic librarian; but, in spite of their serious nature, the ACRL Committee on Academic Status has suggested to the profession, through an article by McAnally, ${ }^{44}$ a certain set of guidelines for the professional conduct of the library faculty. These seventeen recommendations suggest to academic librarians what needs to be done to develop within the library faculty the techniques of governance and the collegial culture that will make them acceptable to the teaching faculty as colleagues. Unfortunately, they leave unanswered the basic questions of the professionalism of librarianship and seem, therefore, to have a less than effective impact.

\section{TENURE}

Among the seventeen recommendations in McAnally's article is the suggestion that library faculty in a university should receive tenure on the same basis as teaching faculty. The question of tenure has been addressed in the recent literature. Branscomb stated that tenure "implied freedom to carry on the work of the library, conduct research and engage in extramural activities...."45 Weber discusses the concept of tenure and distinguishes both the need to protect the academic freedom of librarians and the need 
to encourage the career commitment of able men and women to the profession. ${ }^{46} \mathrm{He}$ does, however, see the process as a modification of the traditional concept of tenure for teaching faculty. Both Branscomb and Weber give lists of elements of intellectual freedom for librarians. Weber suggests four reasons for tenure for librarians: (1) book selection responsibilities; (2) dissemination of information on all subjects; (3) preparation of bibliographies or exhibits; and (4) advising students in reading. Branscomb lists twelve activities of librarians requiring the protection of the tenure umbrella.

A number of writers have discussed tenure as part of a program of collegial governance for library faculty and an element in the process of promotion of faculty. ${ }^{47,48}$ Blake presents the case for giving tenure to academic librarians $s^{49}$ and quotes the formal statement on tenure published by the AAUP in 1940 as follows:

Tenure is a means to certain ends, specifically, (1) freedom of teaching and research, and of extramural activities; and (2) a sufficient degree of economic security to make the profession attractive to men and women of ability.

Among all these arguments, it is difficult to discern any cogent reasons for the practice as suggested for librarians, however. There may indeed be situations in the life of an academic librarian when he or she is in jeopardy in the performance of professional duties, but these are difficult to imagine. Perhaps the process of book selection or the elaboration of public exhibits might be the target of undue pressure, but unlike the scholar-teacher the librarian is seldom in the position of questioning accepted knowledge and values. Emerson put the matter succinctly:

The university is generally conceived as performing two main functions in a democratic society. One is the transmission of existing knowledge and values to the on-coming generation. The other is the critical re-examination of such knowledge and values, with a view to facilitating orderly change in society. ${ }^{30}$

The protection of tenure is extended to the scholar especially in the second function of the university. But in the very nature of his work the librarian is seldom engaged in such a reexamination. When it comes down to it, tenure is the protection extended to a university teacher when his professional goals and responsibilities are in conflict with institutional goals. It "is regarded as the major guarantee of freedom because it puts the instructor beyond the easy reach of administrative tyranny or the quixotism of governing boards." 51 One can question whether the professional goals and responsibilities of academic librarians would ever be in conflict with institutional goals, so identified have they been in the past with bureaucratic structures of Academia.

\section{Collegiality}

Faculty status for academic librarians has greater meaning than merely bestowing faculty rank or titles on librarians or making available to them faculty perquisites. These are but the outward symbols of a corporate existence that is the natural domain of the university teacher, and indeed of the members of any profession. That corporate existence is described by the term collegium. The advent of faculty status for university librarians implies, therefore, that the corps of professional librarians in the university is organized as a college. There follow from such an organization a number of important consequences.

The members of the collegium bibliothecariorum first of all share responsibility, as a body of professional workers, for the quality of library service in the university. It is presumed also that, understanding through their professional training the goals of the profession, they will participate in the formulation of the programs in this university to achieve those goals. Again, it is assumed that all the librarians accept responsibility for the quality of the library faculty and, to fulfill that responsibility, they will organize themselves in such a way as to promote the quality of the faculty in recruitment of new members of the collegium and the professional growth of its present members. Finally, the members of the library faculty are expected to join with the members of other faculties in the work of governance within the larger domain of the universitas.

Writers in the professional literature have treated all these aspects of collegiality. Volkersz notes that, in breaking out of the hierarchical structures of the past, librarians 
will, together with the teaching faculty, participate in making the crucial decisions shaping their contributions to teaching, research, collection development, and community involvement. ${ }^{52}$ McAnally has given an extensive formulation to the privileges and obligations of library faculty, with special attention to the questions of criteria for appointment and promotion for librarians. ${ }^{53}$ Hintz has conducted a survey of academic librarians on the topic and has assembled recommendations for criteria for promotion on the basis of this sampling of opinion. ${ }^{54}$

The obligations of faculty status that bear directly on the individual librarian arise from the policy statement on criteria for appointment and promotion: the obligation to perform research, publish, and serve on university bodies. Kellam has reviewed the activities and opportunities of university librarians to such avenues of professional growth as reported from a survey of ARL directors. ${ }^{55}$ Jesse also has treated this topic. ${ }^{56}$

Collegiality for librarians in the university has, however, some inconvenient problems. Bailey noted some effects of faculty status on the supervision of the library and pointed out that librarians with faculty status have three overlapping aspects of service: personal expertise, administrative position, and professional status. ${ }^{57}$ She discusses in her paper the confusion arising from the introduction of collegial relationships into an organization (the library) that is essentially hierarchical. There appears to be a considerable amount of negative feeling on the part of professional staff (especially middle management) toward collegiality. The trouble centers around the fact that, in forms of collegial governance, the locus of decision making is not clear; that collegial decisions may conflict with administrative intent; and that advancement avenues are not clear, since two tracks for advancement are in view: faculty and administrative hierarchy.

Tallau raises the same problems of overlapping and conflicting commitments of librarians who find themselves, through historical change, confronted with the consequences of faculty status. ${ }^{58}$ She points out quite effectively that faculty status usually has been seen by librarians as equality with and acceptability to the teaching faculty, rather than affecting relations within the library. This is emphatically not so. Collegiality has great implications for the academic librarian's relations with: (1) the faculty; (2) students; (3) the administration; and (4) his or her colleague librarians. Tallau goes on to show that the current movement toward participative management in business organizations, and in the academy, has raised some of the same problems in its impact on bureaucratic management structures.

Perhaps the most telling criticism of the concept of collegial governance for university librarians comes from Beckman. ${ }^{59}$ After remarking on the published standards for faculty status and the encouragement of ACRL to establish collegial governance, Beckman points out that "this view is contentious for two reasons." The first of these is that directors of libraries have a different accountability than deans of faculties. The second is that the bureaucratic administration of libraries can be mitigated by other means than collegial governance, chiefly through participative management techniques.

It is true that the accountability of academic department chairpersons and deans is thought of as different from that of the library director. The professoriate has one primary function: teaching. "Within the teaching activity, each faculty member is independent as to methodology, timing, and even to a certain extent scheduling. The dean may be to a certain extent accountable for such coordination of teaching programs as is necessary, but he is not accountable for the performance of the teacher in the classroom."60 On the contrary, that is the responsibility of the professor in his clientprofessional relationship.

The director of libraries, on the other hand, is seen to be directly responsible to the university administration for all library service because of his or her position as a member of the university hierarchy; the performance of all the librarians is laid at the feet of the director. Collegiality, however, imposes new dimensions of responsibility on the entire library faculty, since it assumes that each librarian, like the professor, acts on the authority of expert knowledge in the client-professional relationship. 
Collegiality also introduces a second role for the chief librarian, that of dean of the library faculty, a role that may be partly unnecessary (in view of the mitigation of bureaucratic rigor by participative management) and is certainly confusing in the context of a hierarchical organization.

Underneath this contretemps there lies again the fundamental conflict endemic in all hierarchical organizations that employ staffs of professional workers: the conflict between the autonomy of the professional speaking with the authority of expert knowledge and the authority of administrative power.

Participative management is a topic that overlaps the concerns of collegial governance; both are systems of organization that are in conflict with hierarchical structures, the very structures that were for many years the hallmark of academic libraries. This suggests, perhaps, that collegial governance and participative management techniques may not be antithetical but complementary. Both Dillon and Williamson ${ }^{61}$ have pointed out in their discussion of the teaching-library concept at Swarthmore and at Sangamon State that as the educative function grows to occupy the full attention of the library faculty, the business functions (acquisitions, cataloging, circulation, etc.) are turned over to highly trained paraprofessionals whose commitment to the organization and valuable contributions are elicited through a program of participative management. Librarians are thus freed to accomplish their professional work.

\section{Collective BaRgainING}

The fabric of collegial governance, which so distinguishes the faculty from the administrative hierarchy of the university, has of late been broadened in some institutions by the adoption of the structures of collective bargaining, a borrowing from the world of labor relations. Collective bargaining is a system of countervailing power. That is, it is a sociological technique for confronting the economic power of the employer with equal power in the hands of employees so that negotiations on matters of common interest to employers and employees can proceed justly, without threat or intimidation. Collective bargaining is supported by Amer- ican society through federal laws that require both labor and management to bargain in good faith. The objectives of collective bargaining are wages and working conditions of the employees.

The history of collective bargaining is closely connected to the trade-union movement both here and abroad. A technique of labor-management relations, it was developed as a product of trade unionism. The use of collective bargaining by occupational groups outside of trade unions is a growing phenomenon of our time, however. This is especially true in the "white collar" occupations. For a long time use of collective bargaining by white-collar workers was resisted by reason of its association with a class ideology. Modern white-collar workers have simply adopted the technique and fit it to their own middle-class ideology.

Adoption of collective bargaining by employed professionals is part of this general trend to extend collective bargaining to other occupational groups. Goldenberg has suggested a number of pressures in organizations employing professionals that may account for the move to collective bargaining. They include: (1) the impersonal work relations in the modern economy; (2) blocked channels of communication between professionals and the employer/client; (3) the decline of personal mobility and its loss as a bargaining weapon; and (4) professional autonomy. ${ }^{62}$

The move to collective bargaining in universities and colleges has been part of the spread of the technique among white-collar workers. The trend began in the two-year state institutions and has been extended through state-supported higher education in New York City, New York State, Massachusetts, New Jersey, California, and many other states. A phenomenon closely associated with this trend is the development of the professional association as a bargaining agent. The American Federation of Teachers has taken an aggressive lead in this process, followed by the National Education Association, and lately by the American Association of University Professors. Among colleges and universities there are now almost 500 employing collective bargaining.

Collective bargaining is a system of coun- 
tervailing power. The university, however, is an organization structured on the hard realities of shared power. The power of the university professor rests on the authority of expert knowledge; the power of the administration rests on economic and legal control. Adoption of collective bargaining by colleges and universities introduces an instrument of countervailing power into an employee-management situation where power itself is already an issue.

("Shared power" is a term often used to describe the relationship between faculty and administration in a collective bargaining context. Shared power is an ambiguous term, however, and many writers have failed to distinguish its two meanings. In the university there is more precisely "confederated power," a coexistence of the authority of expert knowledge resting in the faculty and the bureaucratic power of the administration. In this case the source of faculty authority is independent of the administration. In programs of participative management there is talk of shared power, but this power sharing is by delegation from hierarchical authority. In this second case the source of shared authority is dependent on the administration.)

Librarians who are seeking faculty status have an obligation to themselves to be aware of the complex situation into which they may be moved in the event that collective bargaining comes to the campus. That librarians are aware in part of these aspects of academic collective bargaining can be seen in Guyton's comments that the "activities of library unions suggest two areas where [bargaining issues] have occurred (1) economic renumeration; and (2) participation in library administration." 63 This second issue is an echo of the tension in the university between faculty and administrative authority.

Weatherford has explored the interactions of the librarians' search for faculty status in a perceptive work. ${ }^{64} \mathrm{He}$ also has given an excellent historical summary of the formation of bargaining units in colleges and universities. (The special histories of the advent of collective bargaining at Wayne State has been told by Spang, ${ }^{65}$ and at West Chester State College by Burns and Carter. ${ }^{66}$ ) In discussing issues to be bar- gained, Weatherford points out that, aside from wages, salaries, benefits, and conditions of work, which are exact analogies from industry, academic collective bargaining can also address itself to the participation in governance as a bargainable issue. ${ }^{67}$ $\mathrm{He}$ also quotes Alfred Sumberg of the AAUP as saying that "faculties should regard collective bargaining as a means of putting into effect the goals of the past fifty years." Collective bargaining is a means for the faculty to counteract the accumulated power of the "managerial middle class" that has grown up in universities.

The twentieth Allerton Park Institute, held in 1974, was devoted to the topic of collective bargaining in libraries. ${ }^{68}$ In the discussions of this meeting the suggestion was made that academic collective bargaining would very quickly move from Maslow's Level I goals to Level II goals. The following Level II goals were suggested as appropriate as bargaining goals: autonomy, occupational integrity and identification, individual career satisfaction, and economic security and enhancement. How realistic these goals are in defining exact issues for the bargaining table remains to be seen.

The institute did, however, raise a serious problem, one that may prove to be extremely difficult for librarians. Within any campus group the university librarians are a minority. Striving for faculty status in the university means, for academic librarians, striving for minority status as well. Where union organization of faculty does not exist, minority status may be little or no disadvantage. With collective bargaining, however, the picture is drastically changed. Unless library faculty are a tightly organized, coherent, and assertive group within the faculty, there may be grave danger that their interests will be compromised at the bargaining table by the larger group. In the words of the institute proceedings: “. . . in the bargaining process the interests of the librarians are going to be diluted by the interests of the matrix group, unless librarians articulate their professional goals. . .."69

Collective bargaining brings to the campus a sharply defined adversary relationship between faculty and administration. The definition of this relationship imposes distinctions of union-management throughout 
the campus. The university library will not be spared such trauma and the subsequent polarization of staff. Much progress is being made in these times toward democratization of library administration through techniques of participative management. These advances may be lost in the polarization of relations between members of the bargaining unit and librarians excluded from it by reason of their administrative position.

\section{ConClusions}

Much has been written about faculty status for academic librarians in American universities and colleges and a fair sample of that literature has been mentioned in the foregoing discussion. Yet much of what has been written lacks the breadth of view that can integrate and explain. Beneath the demands of academic librarians for recognition in the academy lie some fundamental issues that cannot be ignored. Chief of these is the question of professionalism, and a second, hardly less important, is the characteristic of the university as an organization of confederated power employing professionals within a bureaucratic matrix.

Whether librarianship is a profession, is becoming a profession, or is a semiprofession is a question that has been given some attention by sociologists interested in human occupations, and their analyses have been very helpful. On the basis of their analyses, one can identify two key questions for librarianship: the sufficiency (or insufficiency) of the knowledge base in theory; and the importance accorded library service by society, especially in the client-practitioner relationship. Even without reference to the works of sociological analysis, many of those who have written about faculty status for librarians seem to be aware of the deficiency in the body of theory supporting the profession. Volkersz, Thompson, and Smith have laid the insufficiency at the feet of the library schools, and Knapp has quoted Dr. Shera to the effect that the knowledge base "lacks underpinning." Many also, as Lancour, have spoken of the need for community sanction of our professional role. That sanction itself rests on the quality of the knowledge base, for as Lancour remarks:

Specifically the profession seeks to. prove that the performance of the occupational skill requires specialized education: that those that possess this education in contrast to those who do not deliver a superior service; and that the human need being served is of sufficient social importance to justify the superior performance. ${ }^{70}$

Society's need for information and librarians' possession of the keys to the information source lie, then, at the root of the question. Smith points out that the social need for information is growing and, in the age of electronic data processing, the complexity of the keys is increasing; he suggests, therefore, that this body of expertise and the underlying information theory quickly be made part of the profession's knowledge base. ${ }^{71}$ Yet many in society still feel that they can do for themselves what librarians claim to be able to do better, and nowhere is this attitude on the part of the client group more prominent than among college and university professors.

Claims for faculty status in the university situs of the profession are thus seriously affected by the perception of the profession by that part of the client group, the professoriate, who are the most influential and whom librarians seem most anxious to emulate. University professors may be wrong in their perception of librarianship; Williamson, who has been in both roles of professor and librarian (in that order) and can speak with authority, states that "faculty members are but dimly aware" of the intellectual complexity of bibliographical control and do not see the knowledge of it as "a worthy discipline in itself." 72 Nevertheless, it is the faculty's perception of librarianship that the profession must deal with. One might add that this clientele can only be convinced of the adequacy of librarianship's knowledge base by intellectually satisfying arguments. Such theoretical statement has yet to be made. In the meantime professors continue to see their librarian colleagues as vocationally trained "assistants," a view that is not mitigated by the sometimes strong vocational orientation and behavior of many members of academic library staffs.

The librarians' apparent lack of perception of what it means to be a professional is also at the root of many of their practical difficulties in seeking recognition in the academy. There seems to be little recognition among librarians of the tension in the 
power relationships within the university, and, consequent upon those tensions, the often compromising positions the university's librarians find themselves in between faculty and administration. A sense of their own professional identity, of the professional identity of their teaching colleagues, and what that means in the matrix of confederated power in the university would make librarians' efforts to achieve academic status more effective because they would be better directed and more realistic.

Those efforts are directed principally (in our day) to the recognition of the librarianas-educator, with some (not enough) attention given to the ideal of librarian-asscholar. But are such efforts, in the main, realistic? Without a strong knowledge base and an adequate body of supporting theory to transmit to the oncoming generation can the teaching of librarians be anything but imperfect? It is not that there is no corpus of knowledge in scholarship to transmit, as some shallow-thinking members of the professoriate would claim. The experiments at Swarthmore and Sangamon State belie that assertion. It is, rather, that our contribution to the educational program of the institution we serve is often offered on a base of insufficient preparation (our own) to a clientele whose perception of the value of that offer to their students precludes their acceptance of it as a serious part of the educational program.

The apparent unawareness of academic librarians of the social dynamic of the university and the role of professionalism (of the faculty) in that drama puts them at a great disadvantage when they attempt, at the urging of their professional society, to assume the roles of collegial governance. Caught between the faculty and the administration, between professional authority (the faculty's) and bureaucratic authority, their bid for status must sail the stormy waters between Scylla and Charybdis. But this unhappy situation has even more difficult manifestations within the university itself, because of the bureaucratic nature of many library administrations. Collegial relations between professional members of a library staff in such a situation will produce great internal strain. Fortunately, progress in the art of administration in the direction of participative management is helping to ease the transition from authoritarian to collegial forms.

Through the process of participative management, the library faculty may, indeed, be able to achieve a meaningful form of collegial governance and a (future) recognition of their role in the academy. Other aspects of library administration, chiefly the housekeeping functions, will undoubtedly remain administrative structures, reporting to the hierarchy of the university but mitigated by the processes of participatory management.

Into this complex and often misunderstood set of relationships in the sociology of the university and the university library there is now introduced the problem of collective bargaining. The power relationship between the professoriate and the administration has, in many institutions, created through increasing tension the movement toward collective action by the faculty. The earlier reservations faculty may have had about the class-ideology base of collective bargaining have been swept away.

This new development in the power struggle within the academy cannot help but affect the library faculty. Their strivings for faculty status may be brought to an abrupt halt in a hearing before the NLRB on the composition of the bargaining unit; or, even if they succeed in maintaining their faculty status within the bargaining unit, their interests may be compromised at the bargaining table by a failure of representation in the union offices and committees. The advent of collective bargaining is simply the ultimate test, for librarians, of their cohesiveness as a professional group, their commitment to the profession, their understanding of the power relationships within the academic situation where they work, and their ability to convince the principals in this struggle of the validity of their claims.

\section{REFERENCES}

1. For an excellent bibliography of this literature see Nancy Huling, "Faculty Status-A Comprehensive Bibliography," College \& Research Libraries 34:440-62 (Nov. 1973). L. J. Pourciau in his doctoral dissertation, The Status of American Academic Librarians (Indiana University, 1975), also includes a valuable bibliography.

2. Robert B. Downs, "The Status of University 
Librarians in Retrospect," College $b$ Research Libraries 29:253-58 (July 1968). See also Howard W. Winger, "Aspects of Librarianship: A Trace Work of History," Library Quarterly 31:321-35 (Oct. 1961).

3. Patricia B. Knapp, "The College Librarian: Sociology of a Professional Specialization," College \& Research Libraries 16:66-72 (Jan. 1955); W. Porter Kellam, "Activities and Opportunities of University Librarians for Full Participation in the Educational Enterprise," College \& Research Libraries 29:19599 (May 1968); Raj Madan and others, "The Status of Librarians in Four-Year State Colleges and Universities," College $b$ Research Libraries 29:381-86 (Sept. 1968).

4. Amitai Etzione, Modern Organizations (Englewood Cliffs, N.J.: Prentice-Hall, 1964), p.76ff.; William J. Goode, "The Theoretical Limits of Professionalization," in Amitai Etzione, ed., The Semiprofessions and Their Organization (New York; Free Pr., 1969); William J. McGlothlin, "The Accommodation of Specialization," Library Quarterly 31:35668 (Oct. 1961).

5. Ernest Greenwood, "Attributes of a Profession," Social Work 2, no.3:45-55 (July 1957).

6. Howard W. Vollmer and Donald L. Mills, eds., Professionalization (Englewood Cliffs, N.J.: Prentice-Hall, 1966).

7. Etzione, Modern Organizations.

8. William J. Goode, "The Librarian: From Occupation to Profession?" Library Quarterly 31:306-20 (Oct. 1961).

9. Goode, "The Theoretical Limits of Professionalization."

10. Gardner Hanks and C. James Schmidt, "An Alternative Model of a Profession for Librarians," College \& Research Libraries 36:17587 (May 1975).

11. Mary Lee Bundy and Paul Wasserman, "Professionalism Reconsidered," College \& Research Libraries 29:5-26 (Jan. 1968).

12. Theodore Caplow, The Sociology of Work (Minneapolis: Univ. of Minnesota Pr., 1954), p. $139-40$.

13. Goode, "The Librarian: From Occupation to Profession?"

14. Shirley B. Goldenberg, Professional Workers and Collective Bargaining (Canada, Privy Council, Task Force on Labour Relations, study no.2 [Ottawa: The Queen's Printer, 1968]).

15. Eldred Smith, "Academic Status for College and University Librarians: Problems and Prospects," College \& Research Libraries 31:7-13 (Jan. 1970).

16. American Library Association, Association of College and Research Libraries, "Joint Statement on Faculty Status of College and University Librarians," College \& Research
Libraries News 33:209-10 (Sept. 1972).

17. A few of the representative early writings on the subject are listed here: W. N. Chattin Carlton, "College Libraries and College Librarians: Views and Comments," Library Journal 31:751-57 (Nov. 1906); Edith M. Coulter, "The University Librarian; His Preparation, Position and Relation to the Academic Department of the University," American Library Association Bulletin 16:271-75 (March 1922); William Warner Bishop, "The Library in the American College," College and Reference Library Yearbook 1:1-12 (1929); B. Harvie Branscomb, Teaching with Books; A Study of College Libraries (Chicago: American Library Assn., 1940).

18. Frank A. Lundy, "Faculty Rank of Professional Librarians," College \& Research Libraries 12:113 (April 1951).

19. Lawrence S. Thompson, "Preparation and Status of Library Personnel," Library Trends 1:95-104 (July 1952).

20. Felix Reichmann, "Hercules and Antaeus," College \& Research Libraries 14:22-25 (Jan. 1953).

21. Robert H. Muller, "Faculty Rank for Library Staff Members in Medium-sized Universities and Colleges," American Association of University Professors Bulletin 39:421-31 (Sept. 1953).

22. Downs, "The Status of University Librarians in Retrospect."

23. Robert B. Downs, "The Current Status of University Library Staffs," College $\downarrow R e$ search Libraries 18:375-85 (Sept. 1957).

24. Robert B. Downs, "Status of University Librarians, 1964," College o Research Libraries 25:253-58 (July 1964).

25. Carl Hintz, "Criteria for Appointment to and Promotion in Academic Rank," College \& Research Libraries 29:341-46 (Sept. 1968).

26. American Library Association, Association of College and Research Libraries, "Model Statement of Criteria and Procedures for Appointment, Promotion in Academic Rank, and Tenure for College and University $\mathrm{Li}$ brarians," College \& Research Libraries News 34:192-95 (Sept. 1973); 34:243-47 (Oct. 1973).

27. Critique of a College, Reports of the Commission on Educational Policy, the Special Committee on Library Policy [and] the Special Committee on Student Life (Swarthmore, Pa.: The College, 1967).

28. John G. Williamson, "Swarthmore College's 'Teaching Library' Proposals," Drexel Library Quarterly 7:203-15 (July-Oct. 1971).

29. Howard W. Dillon, "Organizing the Academic Library for Instruction," Journal of Academic Librarianship 1:4-7 (Sept. 1975). 
30. Raleigh DePriest, "That Inordinate Passion for Status," College \& Research Libraries 34:150-58 (March 1973).

31. Knapp, "The College Librarian."

32. John H. Moriarty, "Academic in Deed," Col lege b Research Libraries 31:14-17 (Jan. 1970).

33. Reichmann, "Hercules and Antaeus."

34. Knapp, "The College Librarian."

35. Winger, "Aspects of Librarianship."

36. Thompson, "Preparation and Status of Library Personnel."

37. Evert Volkersz, "Library Organization in Academia: Changes from Hierarchical to Collegial Relationships," in E. J. Josey, New Dimensions for Academic Library Service (Metuchen, N.J.: Scarecrow, 1975), p.77-85.

38. Smith, "Academic Status for College and University Librarians."

39. Ibid.

40. Cf. Thompson, "Preparation and Status of Library Personnel," who quotes L. C. Powell: "On every academic staff I have any aquaintance with, I can count on a few fingers the number of persons who can establish intellectual camaraderie with the faculty. Until this can be done by the majority of the staff, talk of equal rank with the faculty is a waste of breath."

41. Hintz, "Criteria for Appointment to and Promotion in Academic Rank."

42. Fritz Veit, "The Status of the Librarian according to Accrediting Standards of Regional and Professional Associations," College ¿ Research Libraries 21:127-35 (March 1960).

43. Downs, "The Current Status of University Library Staffs."

44. Arthur M. McAnally, "Privileges and Obligations of Academic Status," College \& Research Libraries 24:102-8 (March 1963).

45. Lewis C. Branscomb, "Tenure for Professional Librarians on Appointment at Colleges and Universities," College \& Research Libraries 26:297-98, 341 (July 1965).

46. David C. Weber, "'Tenure' for Librarians in Academic Institutions," College \& Research Libraries 27:99-102 (March 1966).

47. Hintz, "Criteria for Appointment to and Promotion in Academic Rank."

48. William H. Jesse and Ann Mitchell, "Professional Staff Opportunites for Study and Research," College \& Research Libraries 29:87100 (March 1968).

49. Fay M. Blake, "Tenure for the Academic Librarian," College \& Research Libraries 29:502-4 (Nov. 1968).

50. Thomas I. Emerson and David Haber, "Academic Freedom of the Faculty Member as Citizen," Law and Contemporary Problems 28:547 (1963).
51. Henry M. Wriston, "Academic Tenure," The American Scholar 9:339-49.

52. Volkersz, "Library Organization in Academia."

53. McAnally, "Privileges and Obligations of Academic Status."

54. Hintz, "Criteria for Appointment to and Promotion in Academic Rank."

55. Kellam, "Activities and Opportunities of University Librarians."

56. Jesse and Mitchell, "Professional Staff Opportunities for Study and Research."

57. Martha J. Bailey, "Some Effects of Faculty Status on Supervision in Academic Libraries," College \& Research Libraries 37:48-52 (Jan. 1976).

58. Adeline Tallau, "Faculty Status and Library Governance," Library Journal 99:1521-23 (June 1, 1974).

59. Margaret Beckman, "Implications for Academic Libraries," in University of Illinois, Urbana, Graduate School of Library Science, Collective Bargaining in Libraries (Urbana, Ill., 1975; Allerton Park Institute, 20th, 1974), p.122-45.

60. Ibid.

61. Dillon, "Organizing the Academic Library for Instruction"; Williamson, "Swarthmore College's 'Teaching Library' Proposals."

62. Goldenberg, Professional Workers and Collective Bargaining.

63. Theodore L. Guyton, Unionization, the Viewpoint of Librarians (Chicago, Ill.: American Library Assn., 1975).

64. John W. Weatherford, Collective Bargaining and the Academic Librarian (Metuchen, N.J.: Scarecrow, 1976).

65. Lothar Spang, "Collective Bargaining and University Librarians: Wayne State University," College \& Research Libraries 36:106-14 (March 1975).

66. Mary Anne Burns and Jeanette Carter, "Collective Bargaining and Faculty Status for Librarians: West Chester State College," College \& Research Libraries 36:115-20 (March 1975).

67. Weatherford, Collective Bargaining and the Academic Librarian.

68. University of Illinois, Urbana, Graduate School of Library Science, Collective Bargaining in Libraries (Urbana, Ill., 1975; Allerton Park Institute, 20th, 1974).

69. Ibid.

70. Harold Lancour, "The Librarian's Search for Status," Library Quarterly 31:369-81 (Oct. 1961).

71. Smith, "Academic Status for College and University Librarians."

72. Williamson, "Swarthmore College's 'Teaching Library' Proposals," p.210-11. 